\title{
Theory or Attitude? A Comparative Analysis of Turkish Newspaper Articles on Turkish Foreign Policy, June 2008-June 2011
}

\section{Metin Gurcan}

To cite this article: Metin Gurcan (2013) Theory or Attitude? A Comparative Analysis of Turkish Newspaper Articles on Turkish Foreign Policy, June 2008-June 2011, Turkish Studies, 14:2, 346-371, DOI: 10.1080/14683849.2013.805059

To link to this article: http://dx.doi.org/10.1080/14683849.2013.805059

曲 Published online: 26 Jun 2013.

Submit your article to this journal $\widetilde{ }$

Џ Article views: 373

Q View related articles ¿

Citing articles: 2 View citing articles 5 


\title{
Theory or Attitude? A Comparative Analysis of Turkish Newspaper Articles on Turkish Foreign Policy, June 2008-June 2011
}

\author{
METIN GURCAN \\ Department of Political Science, Bilkent University, Bilkent/Ankara 06800, Turkey
}

\begin{abstract}
Turkish Foreign Policy (FP) has seen a paradigmatic transformation. This study presents a comparative analysis of 1535 articles, written by more than a hundred columnists and published in ten Turkish newspapers between June 2008 and June 2011. Results show a strong polarization of opinion such that articles with realist theoretical stance are highly likely to be critical of the Justice and Development Party's (AKP) FP for Turkey, whereas articles with liberal and constructivist theoretical stance are highly likely to have pro-government positioning. In this close association, the question is whether attitude to government policy precedes or follows theoretical stance. Results suggest that newspapers employ mostly whatever theory will support their stance for or against the AKP's new-era FP. In addition, results suggest little attention to Turkey's bid for European Union membership and little attention to world problems outside the Middle East.
\end{abstract}

If there were only one truth, you couldn't paint a hundred canvases on the same theme.

Pablo Picasso, 1966

\section{Introduction}

Turkish Foreign Policy (FP) has been in a period of transformation in recent years, as Turkey has experienced important changes in both internal and external political relations. In parallel with the increase of the visibility of Turkish FP both in the international and domestic domain, there has emerged a great curiosity to understand the dynamics of these changes. Ahmet Davutoğlu, the current Minister of Foreign Affairs of Turkey, who has made a great contribution to the paradigmatic shift, asserts that "over the past seven years, Turkey has been able to formulate a systematic and

Correspondence Address: Metin Gurcan, Department of Political Science, Bilkent University, 06800 Bilkent/Ankara, Turkey. Email: metin.gurcan@bilkent.edu.tr 
cohesive methodological approach to world affairs because its political party (Justice and Development Party (AKP), Adalet ve Kalkınma Partisi) has been able to govern, resulting in real political stability at home." ${ }^{1}$ Davutoğlu suggests three methodological and five operational principles that drive Turkey's FP today.

The methodological principles include "visionary approach to the issues instead of the crisis-oriented attitude that dominated FP during the entire Cold War period," "basing Turkish FP on a consistent and systematic framework around the world," and "the adoption of a new discourse and diplomatic style, which has resulted in the spread of Turkish soft power in the region."2 The operational principles are: a "balance between security and democracy, zero problems toward neighbors, proactive and pre-emptive peace diplomacy, multi-dimensional FP which sets Turkey's relations with other global actors aim to be complementary, not in competition," and finally "rhythmic diplomacy which aspires to provide Turkey with a more active role in international relations." 3

It is not a hyperbole to state that this ambitious vision of a new Turkish FP intends to transform both Turkey and the region not merely politically, but also in economic and cultural ways. The self-reliance of the AKP, its independent tailoring of FP parameters, and the increasing visibility of Turkish FP in the global arena are significant indicators of the transformation of FP in the new era. The question is then, in Zaman columnist Ekrem Dumanlı's words, "while the vision of Turkey has been broadening, is the media ready for this wider vision?"4 The findings of this study suggest that the answer may be that the media are not ready.

\section{Methodology and Research Question}

In this study, a qualitative content analysis is applied to examine the corpus of Turkish mass media coverage of Turkish FP. Content analysis is a research method for making replicable and convincing inferences from a corpus of texts with the aim of providing knowledge and new insights. ${ }^{5}$ To perform a content analysis on a given text, the text is coded or broken down into convenient categories on a variety of levels, word, phrase, sentence, paragraph or theme, and then scrutinized, using conceptual or relational analysis. ${ }^{6}$

Qualitative content analysis, a type of content analysis, is designed for "subjective interpretation" of the content of a text through the systematic classification process of coding and identifying themes or patterns. ${ }^{7}$ Qualitative content analysis goes beyond merely counting words or digging out "objective" content from texts to study meanings, themes and patterns that may be latent or buried in a particular text. It enables researchers to realize social reality in a subjective but scientific manner.

In this study, a manual qualitative analysis is conducted to capture overall argument, supportive explanations, theoretical stance and pro/anti-government positioning of each article. Titles, arguments and supportive explanations that establish the meaning in the context are examined to produce both a thematic structure for each article and to obtain the latent context, where the meaning is materialized. Although manual analysis would be insufficient to extrapolate specific details, the abundance 
and decisiveness of themes highlighting the theoretical stances and attitudes of newspaper columnists on the performance of Turkish FP make it possible to grasp the latent context of the samples.

One should note that all words or phrases used in this study are direct quotations from the articles. The name of the columnists, the name of the newspapers and the exact publication date (mm.dd.yy) of the articles from which the direct quotations are taken, and attached to the quotations to provide greater reliability of citations.

\section{Step 1: Collecting data}

To obtain the corpus, a search was conducted in the database within the archive of the author by entering the key word "dış politika (FP)" among columnists' articles. With this search, all articles that include the key word "dlş politika" in content were filtered. Then, selected articles were further screened to select articles for analysis. In this further screening, the following criteria were applied to enhance the quality of the sample.

(a) The articles in the sample should solely be on FP (articles addressing other topics along with the FP have not been included)

(b) The articles in the sample should propose a sound argument and lay out sufficient explanations to support this argument (therefore, articles that contain only comments have been omitted)

\section{Step 2: Classification of the corpus}

After coding the themes in all articles, the corpus is first classified according to the theoretical stance. In this step, the articles direct quotes of which some are presented below, for instance, are classified in the realist camp.

- "Russian-Georgian War Still Is A Proof That Realist Doctrine Prevails Over The International System."

- "Lisbon Summit Is A Triumph And Breakpoint Of Practical Politics In The Clash Of Pragmatist/Idealist." 9

- “There Exist Turkey's Expansions, Rising Economical Force, Ascending International Profile, Even More Strategic Efforts To Be A Global Force But Not Enough Capacity To Sustain His Dream." 10

- "Power Should Be Viewed In A Realistic Manner."11

- "Is Turkey A Global Force? We Should Not Forget That The Means-Objective Relationship Is The Basic Rule Of Strategy."12

- "Turkey Should Abstain From Sanction To Iran. What If Iran Produces Weapons In The Future?"13

- "Collapse Of The Davutoglu Legend: Conflict Is A Clear FP Fact In International System."14 
- "After The Gaza, Sudan And Iran Cases, Now Is The Time For Taliban Mediation. What A Fallacy."15

- "Ottoman Society Of Nation Seems Classy, But The Question Is Whether It Is Realistic." 16

The following commonly used phrases defining the Turkish FP are, for instance, good indicators in classifying the articles in which they appeared in the realist camp: realpolitik, outcome-based FP, FP respectful to the geopolitical necessities, concrete, non-populist, traditional, axis shift in FP, FP respectful to the national interests, pragmatist, Westernist, rationalist, effective, [when criticizing the FP] Jihadist solidarity in the FP, Islamist, Middle East-centric, drifting, illusionist, confused, romantic, treacherous, FP with neo-Ottoman fantasies.

In contrast, the articles presented below, for instance, are classified in the liberal camp:

- "Future Belongs To Soft Power."17

- "Regional Vision of Turkey at Mesopotamia Economic Basin.,"18

- "Turkey That Shaking Off The Burdens In Its History And Ripening Its Identity." 19

- "In the new era, Turkish foreign policy has the properties of zero challenge with neighbors, carrying out a proactive reconciliation diplomacy, sustaining relationship with the US and EU based on mutual respect, acting a part at international organizations actively, taking role in global conflicts."20

- "On A Liberal Perspective, Turkey Has An Intention To Convert Its Economical Force Into Diplomatic Influence. But The Main Point Is That Do The Israel Really A Necessary Cost?"21

- "If Tyrant Has Nation-State, Oppressed Ones Have Internationalism."22

The following commonly used phrases helped to classify articles as liberal: moralpolitik, FP with global vision, econo-centric FP, multi-dimensional, FP with soft power, FP with the mediator role, multilateral, idealist and principled, pacifist, humanist, FP changing traditional perceptions, playmaker, proactive.

The articles the direct quotes of which some are presented below are, for instance, classified into the constructivist camp:

- "Turning Back To Middle East Has Psychological Extents In Terms Of Turkey's Leadership."23

- "Cultural And Emotional Territory" Has Gained Importance Much As "Physical Region." 24

- "We need to get rid of the indoctrinated apprehensions and geographical determinism.",25

- "Davos outburst of Erdogan is not getting stubborn but standing staid. Pride is the thing what the Arabian world needs." 26 
- "We should transform Israel by the hands of Turkey to solve regional problems.",27

- "The traditional rigid, outcome-based definitions of FP have been out. It is not the outcomes but processes and identities that shape the FP nowadays."28

- "Turkey is a hybrid country with both Islamic and Western Identities."29

- "When traditional pillars of international system are changing, arguments on axis shift are merely illusions." 30

The following commonly used phrases are good indicators of the constructivist camp: process-based FP, identity-driven, FP of honor, imperial Neo-Ottomanist vision, transformative, FP delivering change and hope, fearless, Turkish FP as the guardian of oppressed ones, trustworthy, courageous FP, FP restructuring the Wider Middle East, FP transforming Israel.

After the classification in terms of the theoretical stance, the corpus, this time, is classified according to the attitude of the columnists toward government's performance on Turkish FP. Six sub-categories: strongly pessimist, pessimist, cautiously pessimist, cautiously optimist, optimist, strongly pessimist are set for this classification. The tone of pro/anti government themes, the degree of praises/criticisms and the nature of praises/criticism (explicit/implicit) are taken as the references for this classification. While, for instance, articles with explicit praises of the personalities of Prime Minister Erdoğan and Foreign Minister Davutoğlu and articles that explicitly portray a grand success story in FP are classified in the strongly optimistic camp; the articles that depict the Turkish FP in the new period as a "success story" are classified in the optimistic camp. The articles with an implicit success story and some reservations are classified in the cautiously optimistic camp; and the articles with the tone of an implicit failure but with some pro-government stipulations are classified in the cautiously pessimistic camp. The articles that explicitly portray a failure and openly criticize the government's performance are classified in the pessimistic camp while the articles with explicit criticisms toward decision makers and that openly depict the shift in the new period as a "systemic break down of Turkish FP" are classified in the strongly pessimistic camp.

\section{Step 3: Analysis}

Among the reviewed articles in each newspaper, the ones with explicit theoretical stance are filtered, sorted and analyzed. Second, among the reviewed articles in each newspaper, the articles with explicit pro/anti government stance are filtered, sorted and analyzed. And then, the filtered articles are cross-tabulated in terms of their theoretical stances and attitudes toward the performance of the government.

Below is the cross-tabulation of articles with explicit themes in terms of attitudes of the columnists toward the Turkish FP's performance and the columnists' theoretical stances:

Table 1 shows that a great majority of realist articles are pessimist on the Turkish FP's performance between June 2008 and June 2011, and a great majority of liberal 
Table 1. Cross-Tabulation of Attitudes toward Turkish FP and Theoretical Stances

\begin{tabular}{lccc}
\hline & \multicolumn{3}{c}{ Theoretical stances } \\
\cline { 2 - 4 } Attitudes toward Turkish FP & Realist & Liberal & Constructivist \\
\hline Pessimist & 162 & 12 & - \\
Optimist & 21 & 80 & 66 \\
\hline
\end{tabular}

and constructivist articles are optimist in this period. What can be inferred from this positioning? Since the columnists have inherently pro-government or anti-government attitudes, do they prefer realist themes to attack government's FP performance or liberal and constructivist themes to defend it?

To answer these question;

(a) The section titled Theoretical Framework will first provide a brief review of what realist, liberal, and constructivist approaches mean.

(b) Analysis section will highlight the findings of the study.

(c) Conclusion will lay out the quantitative and qualitative findings

\section{Theoretical Framework}

If one were to categorize the theoretical themes in the articles analyzed, one may easily find out that these themes can be classified in terms of three widely accepted theories of international relations: traditional realist and liberal theories and the constructivist approach.

\section{Realism}

Like the inhabitants of a wild jungle, in which anarchy and chaos prevails, states in the international system must be self-interested, self-helping, ready for war and must always watch the balance of power. ${ }^{31}$ In this jungle-like international system shaped by anarchy, there is no definition of a good or bad state. That is why, for the states, first survival and then maximizing relative power and hegemony is the ultimate goal. Balance of power and diplomacy, the two most influential instruments in international relations, can correct the imperfections of world politics rooted in the inherently existing malicious nature of man.

The principles of realism are;

- Politics is governed by objective laws rooted in human nature, and the history and cumulative experience of mankind proves that human nature has not changed. Nonetheless, if statesman act rationally and understand the law of nature, policies would be better and the world would be a safer place. ${ }^{32}$ 
- Interests are defined in terms of power and thus motives and ideas matter little. ${ }^{33}$

- The political sphere is autonomous: economic, legal, moral and all other interests are subordinate to interests defined as power. ${ }^{34}$ Politics, therefore, is not a function of ethics. There could be no effective morality where there was no effective authority.

\section{Liberalism}

The primary assumption of the liberal school is that conflict is not caused by the nature of man, but by the imperfections of the society of states. Reasoning, morality, and rationality could improve the world, which is regarded as a "cultivatable land" by this school. ${ }^{35}$ The dependent variable that this school seeks to understand is the degree of institutionalization among states.

There are mainly three different strands of liberalism.

- Economic interdependence makes states less likely to fight. ${ }^{36}$ Stability flows not from military power, but from the creation of a liberal economic order, which is in fact for the wellbeing of everybody in the system. A liberal order fosters economic interdependence, a situation in which states are mutually dependent on each other.

- Democracies do not fight with each other. ${ }^{37}$ Like birds of a feather flocking together, ideological solidarity among democracies prevents conflict.

- International institutions enhance cooperation and therefore reduce the likelihood of conflict. ${ }^{38}$ They could help overcome selfish state behavior by encouraging states to forego immediate gains for the greater benefits of enduring peace.

\section{Constructivism}

The central idea of this approach is that much of the reality in world politics is socially constructed and thus can change, that is, ideas, norms and identities are important. ${ }^{39}$ For constructivists, anarchy, for instance, the primary institution in realist thinking that should be accepted as a pre-determined fact, "is what states make of it" ${ }^{40}$ In contrast to the realists, who define material power (military and economic) as the single most important source of influence and authority in world politics, constructivists suggest that power is more than brute force. To understand how power is distributed in world politics is not the key factor to understand international relations; rather the key is what states understand about that power. ${ }^{41}$ Knowledge, culture, ideology may also be great sources of power. ${ }^{42}$ The real power of social practices, for this approach, lies in the efficiency and rapidity of their meaning-making capacity to first deconstruct conventional meanings and then to reconstruct new meanings in a new socially constructed community. ${ }^{43}$

\section{Analysis}

When the articles are categorized and prioritized in terms of the issues they addressed (Tables 2 and 3); 
TURKISH FOREIGN POLICY IN THE NEW ERA (\%)

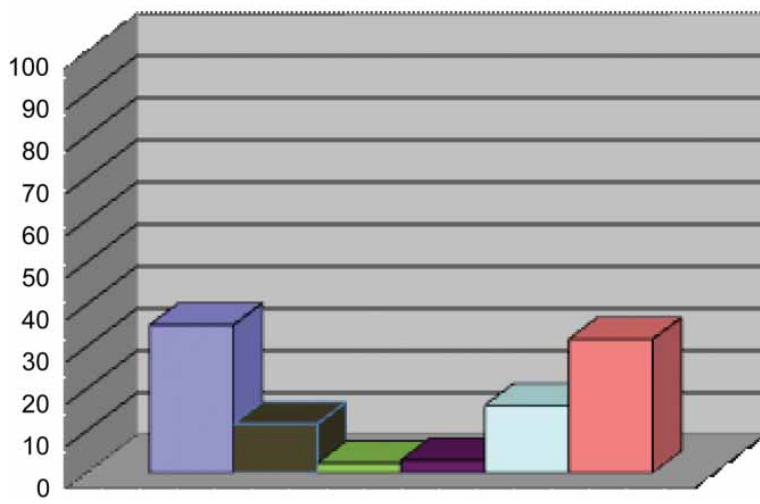

$35.1 \%$ STRONGLY OPTIMIST $11.6 \%$ OPTIMIST $2.3 \%$ CAUTIOUSLY OPTIMIST $3.0 \%$ CAUTIOUSLY PESSIMIST $16.0 \%$ PESSIMIST $31.7 \%$ STRONGLY PESSIMIST

Figure 1. The Perception of the Columnists in Turkish Print Media on the Turkish FP's Performance.

The corpus suggests that there exists a major polarization and cleavage on Turkish FP in the print media that have a cardinal role in embodying the perceptions and beliefs of Turkish public opinion. Among 1535, when 629 articles that include explicit judgment on Turkish FP's performance in the new era are classified according to their evaluation on Turkish FP's performance, the extent of existing polarization and cleavage among opinions leaders in Turkish print media may be easily noticed (Table 4, Figure 1).

One may then recognize the strength of Strongly Optimist (31.7 percent) and Strongly Pessimist (35.1 percent) categories, and the weakness of the intermediate ones. This is the clearest indicator of polarization. In the same vein, the fact that while the articles in Hürriyet are substantially Strongly Pessimist ones, whereas the articles in Zaman are largely in the category of Strongly Optimist, is another indication of this polarization and cleavage in terms of the stances of the newspapers. One may wonder whether the Turkish FP in the new era is dreadful as Hürriyet says, or marvelous as Zaman says. Is Turkish FP ascending or descending? Nuray Mert's words, "Overstate and understate spirals" 44 sums up the dilemma of columnists when positioning themselves relating to Turkish FP in the new era.

On the other hand, when 386 articles with an explicit theoretical emphasis are reviewed (Figure 2 and Table 5).

To answer these questions, the subsequent section will, first, present a brief summary of each newspaper's attitude toward Turkish FP in the new era, and then highlight the negative cases that contradict the general attitude of each newspaper.

\section{Hürriyet}

68 articles (30 percent) out of 231 explicitly include realist themes. Therefore, Hürriyet is the most realist newspaper examined in this study. It is also worth noting that 
Table 2. The Number and Percentage of Selected Articles ${ }^{\mathrm{a}}$

\begin{tabular}{|c|c|c|c|}
\hline Newspaper name & $\begin{array}{l}\text { Approx. } \\
\text { circulation }\end{array}$ & $\begin{array}{l}\text { Number of } \\
\text { analyzed } \\
\text { articles }\end{array}$ & $\begin{array}{l}\text { Percent of } \\
\text { analyzed } \\
\text { articles }\end{array}$ \\
\hline $\begin{array}{l}\text { Milliyet, wide circulating newspaper } \\
\text { owned by Karacan Media Group and } \\
\text { has a publication policy close to a } \\
\text { secularist, liberal centralist stance }\end{array}$ & 130,000 & 260 & 16.9 \\
\hline $\begin{array}{l}\text { Radikal, newspaper owned by the } \\
\text { Dogan Media Group and has a } \\
\text { publication policy close to a leftist } \\
\text { and liberal stance }\end{array}$ & 35,000 & 247 & 16.09 \\
\hline $\begin{array}{l}\text { Hürriyet, the widest circulating } \\
\text { newspaper owned by the Dogan } \\
\text { Media Group and has a publication } \\
\text { policy close to a secularist centralist } \\
\text { and has a anti-government stance }\end{array}$ & 415,000 & 231 & 15.04 \\
\hline $\begin{array}{l}\text { Sabah, newspaper owned by Çalık } \\
\text { Group that has close ties with JDP } \\
\text { and has a pro-government stance }\end{array}$ & 350,000 & 202 & 13.15 \\
\hline $\begin{array}{l}\text { Zaman, newspaper owned by Islamic- } \\
\text { oriented Gülen movement and has a } \\
\text { pro-government stance }\end{array}$ & 900,000 & 147 & 9.57 \\
\hline $\begin{array}{l}\text { Star, the newspaper with a liberal } \\
\text { publication policy and ultra pro- } \\
\text { government stance }\end{array}$ & 125,000 & 111 & 7.23 \\
\hline $\begin{array}{l}\text { Yeni Şafak, the newspaper with a } \\
\text { Islamist and ultra pro-government } \\
\text { stance }\end{array}$ & 110,000 & 106 & 6.90 \\
\hline $\begin{array}{l}\text { Cumhuriyet which has a publication } \\
\text { policy close to a secularist statist- } \\
\text { leftist and has a anti-government } \\
\text { stance }\end{array}$ & 50,000 & 103 & 6.7 \\
\hline $\begin{array}{l}\text { Taraf, the newspaper which has a ultra- } \\
\text { liberal publication policy }\end{array}$ & 55,000 & 78 & 5.08 \\
\hline $\begin{array}{l}\text { Yeniçăg, the newspaper with a ultra- } \\
\text { nationalist publication policy and has } \\
\text { an anti-government stance }\end{array}$ & 50,000 & 50 & 3.25 \\
\hline Total & $2,286,611$ & 1535 & $100 \%$ \\
\hline
\end{tabular}

${ }^{a}$ The Circulation Report was taken from http://www.medyatava.com/tiraj.asp (accessed September 15, 2011). The total newspaper circulation of 35 different newspapers in Turkey is roughly 3.5 million. The total number of $2,286,611$ circulation of these 10 newspapers (as of October 12, 2011) comprise therefore roughly 65 percent of the total newspaper circulation. In this sense, the scope of this study covers around 70 percent of total circulation in Turkey. 
Table 3. The Distribution of the Articles in Terms of Topics They Addressed

\begin{tabular}{|c|c|c|c|}
\hline Nu. & Topics & $\begin{array}{l}\text { Number of } \\
\text { articles }\end{array}$ & Percentage \\
\hline 1 & $\begin{array}{l}\text { US FP and the Turkey-US relations (2008 US } \\
\text { Presidential Elections, Global Crisis, Obama's visits } \\
\text { to Turkey and Egypt, "Obamania" debate, US FP } \\
\text { priorities, Wikileaks documents) }\end{array}$ & 240 & 15.63 \\
\hline 2 & $\begin{array}{l}\text { Israel's FP and the Turkey-Israel relations (Israel's } \\
\text { Gaza attack, Mavi Marmara raid, the termination of } \\
\text { Anatolian Eagle Exercise, the broadcast of serial } \\
\text { "Separation" by TRT, Davos outburst, Israel-Hamas } \\
\text { and the Israeli-Iranian and the Israeli-US relations, } \\
\text { the Israeli lobby in the USA) }\end{array}$ & 175 & 11.40 \\
\hline 3 & Turkey-Middle East relations, Arab Reforms, Libya & 135 & 8.79 \\
\hline 4 & $\begin{array}{l}\text { Praises or critiques on the performance of foreign } \\
\text { minister Ahmed Davutoğlu }\end{array}$ & 102 & 6.64 \\
\hline 5 & Debates on axis shift and identity of Turkish FP & 82 & 5.34 \\
\hline 6 & $\begin{array}{l}\text { Iran and Turkey-Iran relations (Iran's Presidential } \\
\text { Elections and political violence during the elections, } \\
\text { Iran-Syria and Iran-Lebanon relations, Iran's } \\
\text { Nuclear Program, Turkey's "no" vote in the SC of } \\
\text { UN) }\end{array}$ & 81 & 5.27 \\
\hline 7 & $\begin{array}{l}\text { Armenia (Armenian Opening, the so-called Genocide } \\
\text { Debate) }\end{array}$ & 80 & 5.21 \\
\hline 8 & Turkey-EU relations and EU candidacy process & 69 & 4.49 \\
\hline 9 & The Russian-Georgian War & 52 & 3.38 \\
\hline 10 & $\begin{array}{l}\text { Conceptual and theoretical discussions on international } \\
\text { relations and Turkish FP (IR theory, the concept of } \\
\text { power, results-oriented process-oriented } \\
\text { understanding of the idealist-realist understanding of } \\
\text { constructive conflict, sub-headings, such as strategic } \\
\text { depth in case) }\end{array}$ & 47 & 3.06 \\
\hline 11 & $\begin{array}{l}\text { Cyprus (Turkey-Cyprus relations, the EU candidacy } \\
\text { process and Cyprus) }\end{array}$ & 37 & 2.41 \\
\hline 12 & Wikileaks documents & 30 & 1.95 \\
\hline 13 & Turkey-Iraq and Turkey-Northern Iraq relations & 26 & 1.69 \\
\hline 14 & $\begin{array}{l}\text { Energy (oil-gas pipelines, energy security, energy- } \\
\text { political) }\end{array}$ & 25 & 1.62 \\
\hline 15 & $\begin{array}{l}\text { "New Ottomanism" and "Ottoman Commonwealth of } \\
\text { Nations' debate" }\end{array}$ & 24 & 1.56 \\
\hline 16 & Iran-US relations & 21 & 1.36 \\
\hline 17 & Crisis in Darfur, Sudan, Omar al-Bashir & 20 & 1.30 \\
\hline 18 & Missile shield project and the NATO summit in Lisbon & 20 & 1.30 \\
\hline 19 & Syria & 17 & 1.10 \\
\hline
\end{tabular}


Table 3. (Continued).

\begin{tabular}{llcc}
\hline \multicolumn{1}{c}{ Topics } & $\begin{array}{c}\text { Number of } \\
\text { Nu.ticles }\end{array}$ & Percentage \\
\hline 20 & \multicolumn{1}{c}{ Russia's FP, Turkey-Russia relations } & 15 & 0.97 \\
21 & Republican Peoples Party (RPP) FP & 14 & 0.91 \\
22 & Greece (Greek economic crisis, Cyprus) & 14 & 0.91 \\
23 & Afghanistan & 12 & 0.78 \\
24 & Turkey and Hamas & 12 & 0.78 \\
25 & Turkey-France relations & 10 & 0.65 \\
26 & Global economic crisis & 9 & 0.58 \\
27 & China & 4 & 0.26 \\
28 & Other (Turkey-India relations-4, Turkey-Azerbaijan-4, & 17 & 1.10 \\
& Germany-1, Brazil-2, Africa-3, the Kirkuk question- & & \\
& 3) & 1403 & $91.40 \%$ \\
\hline
\end{tabular}

Table 4. The Categories of Articles on Turkish FP's Performance

\begin{tabular}{|c|c|c|c|}
\hline Nu. & Categories & $\begin{array}{l}\text { Numbers of } \\
\text { articles }\end{array}$ & Ratio \\
\hline \multirow[t]{5}{*}{1} & Strongly optimist & & \\
\hline & Hürriyet: 1 Taraf: 16 Star: 9 Yeniçă̆: 2 & 221 & 35.1 \\
\hline & Zaman: 96 & & \\
\hline & Radikal: 20 Milliyet: 9 Sabah: 13 Yeni Safak: 53 & & \\
\hline & Optimist & & \\
\hline \multirow[t]{3}{*}{2} & $\begin{array}{l}\text { Hürriyet: } 7 \text { Taraf: } 12 \text { Star: } 1 \text { Yeniçă̆: } 1 \text { Zaman: } 13 \text { Radikal: } \\
\quad 13 \text { Milliyet: } 12 \text { Sabah: } 17 \text { Cumhuriyet: } 1\end{array}$ & 73 & 11.6 \\
\hline & Yeni Safak: 9 & & \\
\hline & Cautiously optimist & & \\
\hline 3 & $\begin{array}{l}\text { Hürriyet: } 2 \text { Taraf: } 2 \text { radikal : } 2 \text { Milliyet: } 2 \text { Sabah: } 2 \\
\text { Cautiously pessimist }\end{array}$ & 15 & 2.3 \\
\hline 4 & $\begin{array}{l}\text { Hürriyet: } 11 \text { Taraf: } 1 \text { Zaman: } 4 \text { Yeni Safak: } 3 \\
\text { Pessimist }\end{array}$ & 19 & 3.0 \\
\hline \multirow[t]{2}{*}{5} & Hürriyet: 35 Taraf: 7 Zaman: 22 & 101 & 16.0 \\
\hline & Radikal: 22 Milliyet: 97 Sabah: 4 & & \\
\hline \multirow[t]{3}{*}{6} & Strongly pessimistic & & \\
\hline & $\begin{array}{l}\text { Hürriyet: } 102 \text { Cumhuriyet: } 42 \text { Star: } 1 \text { Yeniçağ: } 36 \text { Radikal: } \\
\quad 8 \text { Milliyet: } 11\end{array}$ & 200 & 31.7 \\
\hline & Total & 629 & $100 \%$ \\
\hline
\end{tabular}




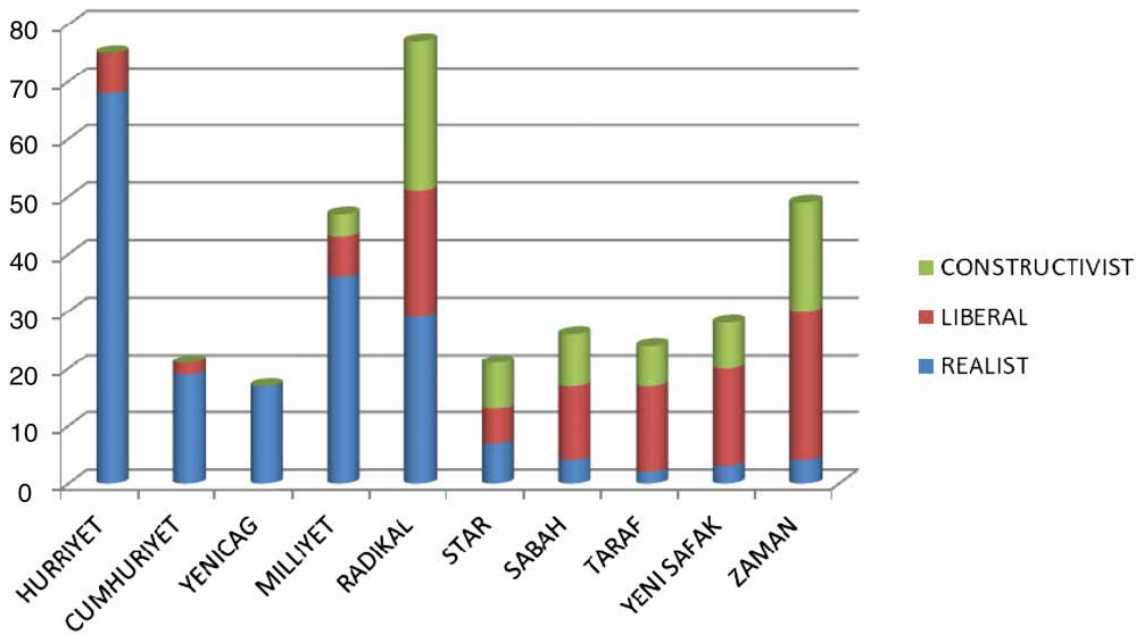

Figure 2. The Theoretical Stances of the Newspapers.

102 articles from the "strongly pessimist" category (44 percent of the total articles in Hürriyet) belongs to Hürriyet.

According to Hürriyet; Turkey, "surrounded by Caucasus Middle East and Balkans, sits in a rough neighborhood." 45 Nonetheless, Turkish FP in the new era, "pursues populist policies for the average man on streets," 46 is "ill-advised, provocative," "47 "uses Islamic references,"48 "facilitates FP issues as instruments for domestic politics,"49 is "US fan to the extent of Obamania," 50 "ineffectively focuses on futile

Table 5. The Categories of Articles on Their Theoretical Emphasis

\begin{tabular}{lcccr}
\hline Newspapers & Realist articles & Liberal articles & Constructivist articles & Total \\
\hline Hürriyet & 68 & 8 & - & 76 \\
Cumhuriyet & 19 & 2 & - & 21 \\
Yeniçağ & 17 & - & - & 17 \\
Milliyet & 36 & 7 & 4 & 47 \\
Radikal & 29 & 22 & 26 & 77 \\
Star & 7 & 6 & 8 & 21 \\
Sabah & 4 & 13 & 9 & 26 \\
Taraf & 2 & 15 & 7 & 24 \\
Yeni Safak & 3 & 26 & 8 & 28 \\
Zaman & 4 & 116 & 19 & 59 \\
Total & 189 & $30 \%$ & $20.9 \%$ & $100 \%$ \\
& $48.9 \%$ & &
\end{tabular}


processes rather than outcomes," 51 "is moving away from the EU and NATO, two traditional instruments anchored Turkey to the West," "f2 "focuses on interpersonal relations rather than institutionalized foreign policy making," 53 "follows an imperial vision rather than national interests," "54 "has shifted to the Islamist ideological ground and embracing global jihad," 55 "has lost traditional western direction," "moves back and forth between fantasy and reality," "We are enough for us" message to the Arabs," "plays the role of U.S. regional subcontractor and neo-Ottoman-looking." ${ }^{, 60}$ Moreover, Hürriyet, which contends that the new setting in Turkish FP has kept it in an "aimless" and "distant" manner, ${ }^{61}$ "proposes that Turkey's tutelage of Omar alBashir of Sudan." ${ }^{62}$ Prime Minister Erdoğan's visit to Iran, ${ }^{63}$ "the mediator role" of Turkey between the USA and the Taliban ${ }^{64}$ has changed "the perception of the West regarding Turkey." ${ }^{65}$ This provocative stance in world politics even if there is no gain for Turkey, has raised some questions such as "Are we still in the western camp?" in the mind of Turkish public. ${ }^{66}$

In Hürriyet, only 13 articles (five percent) in 231 are pro-government and have optimistic themes. A great majority if these negative cases are about President Abdullah Gül's visits to Armenia ${ }^{67}$ Gül's Latin America visit, ${ }^{68}$ Turkey's No vote in the UN Security Council on the sanctions against Iran, ${ }^{69}$ Turkey's Northern Iraq opening ${ }^{70}$ and Turkey's growing influence in the Wider Middle East region. ${ }^{71}$

Also phrases such as "Kasımpaşa bully,",72 "populist FP,"73 "Hamas's speaker,",74 "Sultan Erdoğan,"75 "Erdoğan is Europe's Hugo Chavez,"76 "Islam's Mujahedeen Davutoğlu,",77 "Mujahedeen James Bond Davutoğlu,",78 "Davutoğlu's ideological schizophrenia,"79 "U.S.'s Neo-Ottoman looking sub-contractor,"80 "government's global Jihadist ideology," 81 "Jihadist mentality in Turkish FP," ${ }^{82}$ are persuasive indicators that show the extreme anti-government attitude of Hürriyet.

In conclusion; it is likely that Hürriyet's negative attitude toward government's performance in FP is the primary driver of its publication policy in the period of June 2008-June 2011. When reviewing Hürriyet articles, the realist themes look like a theoretical background to persuasively disseminate this negative stance, which suggests that, in the strong association of negative attitude toward government's FP making and realist stance, negative attitude precedes the theoretical stance. The attacks in Hürriyet's articles to the personalities of AKP's political leaders such as Prime Minister Erdoğan and Minister of Foreign Affairs Davutoğlu support this assumption as well.

\section{Cumhuriyet}

Realist themes triumph in the 103 articles examined in Cumhuriyet. In this regard, after Hürriyet, Cumhuriyet is the second most realist newspaper. One should also note that the number of Strongly Pessimist articles in this newspaper is 42 (40 percent). According to Cumhuriyet, "Turkish FP has erroneously and treacherously slipped from the interest-centric approach to the ideal-centric approach in the new era." ${ }^{83}$ Turkey has "moved quickly away from the West and excessively influenced 
by the US. ${ }^{84}$ Many Turkish economic enterprises have been sold to foreigners with an "econo-Islamist" understanding ${ }^{85}$ and Turkey has eventually been drawn to the "the Middle East quagmire." 86 Turkey, "which has changed her ideological stance by befriending to Hamas, Sudan and Iran," 87 "has ended her enthusiasm in the EU membership process." ${ }^{88}$ Put simply, Turkish FP has been "intoxicated" by the new Ottoman "fantasies," ${ }^{89}$ and strategic depth "drunkenness" on the brink of the Arab Spring. ${ }^{90}$

Among the 103, it is interesting to see only one pro-government article that emphasized "some of the policies of Davutoğlu are true since the US has been a withdrawing power." "91 The phrases such as "Davutoğlu's new Ottoman fantasies," "92 "strategic confusion in the FP" ${ }^{\prime \prime 3}$ are commonly used, which demonstrate the extreme antigovernment attitude of this newspaper. Like the ones in Hürriyet, therefore, the negative attitude on government's performance prevail the theoretical stance in the articles in Cumhuriyet. The attacks in Cumhuriyet's articles on the personalities of AKP's political leaders support this assumption, a point that one can witness in the Hürriyet case as well.

\section{Yeniçă̆}

Among the 50 articles examined in Yeniçăg, 36 were anti-government and 17 were with realist orientation. Yeniçağ claims that the Ottoman millet system, a dream in terms of the objective-means balance. ${ }^{94}$ "The Armenian opening, forced by the US, ${ }^{99}$ "at the expense of alienating Azerbaijan,", ${ }^{96}$ was a "gamble.," ${ }^{97}$ In this new era, Turkey, which has been drafting in "treacherous waters," could not "get any significant result," "romance" currently noticed in the FP of Turkey, "which is currently navigating in foggy seas," 99 will eventually lead to heavy consequences that will be paid by the Turkish nation. ${ }^{100}$

There is only one optimistic article as the negative case in Yeniçăg; this article states "Turkey has tailored a wise foreign policy that balance the US and Russia." ${ }^{101}$ In this sense, it is likely to assert that the negative attitude toward government's performance is obvious in the case of Yeniçă̆.

\section{Milliyet}

In the light of 260 articles examined in Milliyet, one may contend that Milliyet has substantial realist themes, yet they are fewer than the ones in Hürriyet, Cumhuriyet and Yeniçağ. Although they are fewer than realist articles, Milliyet has some liberal themes as well. On the other hand, 26 pro-government articles in Milliyet, most of which were liberal orientations, are worth mentioning. For this reason, this newspaper could be placed between Pessimist and Cautiously Pessimist categories.

According to Milliyet, the Turkish FP makers have been tailoring its policies not by "rationality" but by "emotions." 102 Yet Turkish FP is excessively courageous against Israel, a good example of which is the "One Minute" outburst in the Davos 
Summit; ${ }^{103}$ "its reluctance to show same courage on Darfur," $" 104$ or Hamas ${ }^{105}$ or Iran tempts one to explain this contradiction as "the mujahideen solidarity." 106 In this new era, which reflects "imperial aspirations," 107 one notices not only "declining interest in the EU candidateship" 108 but also shifting the axis of traditional FP. ${ }^{109}$ In the same vein, the "Islamic identity" of Turkish FP has become very visible, ${ }^{110}$ and "generates its political energy from Turkey-Israel conflict." "111 This new approach that disrupts the principles of traditional $\mathrm{FP}^{112}$ has "fallaciously" failed to recognize that there are no "eternal friendships" in international relations, and "interests of the states are the sole determinants of world politics."113

In the pessimistic camp, unlike Hürriyet, Cumhuriyet and Yeniçă̆, in which negative attitude toward government's performance is likely to lead the realist positioning of the articles, Milliyet's articles seem less likely to directly attack the government. In this sense, it would be convenient to position Milliyet in the Cautiously Pessimist camp. When the thematic structures of the articles are reviewed, the theoretical stance in Milliyet seems to lead the columnists' attitudes on government's performance. The writing style of the majority of the columnists in Milliyet, that first portrays a theoretical truth and then efforts to criticize government's performance with cautiously selected and theoretically convenient words, is also worth mentioning as a supportive indicator that underlines Milliyet's grasp of theoretical supremacy rather than the negative attitude toward government's performance.

\section{Radikal}

The first notable finding on Radikal is that the numbers of articles that include realist, liberal and constructivist themes, are almost equal among the 247 articles examined. Radikal, which is usually preferred by more intellectual readers who seek a more critical and investigatory approach, is, therefore, the most neutral newspaper among the 10 examined in this study in terms of both its theoretical stance. Similarly, while 32 articles are optimistic ones, 31 articles negatively address the Turkish FP, which means that Radikal is also the most neutral newspaper among those examined in terms of attitude toward government's performance.

According to Radikal; Turkey has been transforming the wider Middle East region as "Obama's peaceful regional vanguard." "114 "The regional weight and thus assertiveness of Turkey has drastically increased." 115 "The new interpretation of her Ottoman root and multi-dimensional characteristics originated from her soft power" has provided Turkey a new setting to play a more "positive role" in the region. ${ }^{116}$ Furthermore, while "business-oriented and principled mindset of the Turkish FP"117 enables modern references in FP making, "recalling the imperial past has made Turkey more assertive." 118 The pillars of this assertive role are: "the utilization of rhetoric 'Islamic world should be self-sufficient' to reconstruct selfconfidence of the Islamic world," ${ }^{, 19}$ the utilization of soft power to facilitate process-oriented approach to produce "credibility" and "reliability" in the FP, ${ }^{120}$ utilization of Israel as the "ceaseless regional rival," economic power to influence Middle East, Caucasus and Balkans. ${ }^{122}$ "One should 
notice that it is a great fallacy and nonsense to argue that the axis of traditional Turkish FP has shifted while the very fundamentals of political system of the world has been changing." 123 To gain a respected place in the new world order, Turkey should, first, emphasize "moral obligations rather than national interests." 124 If Turkey realizes these dynamics, she may "live the golden era." Turkey is actually a waking "giant."." 25

It is evident that the theoretical stance is more important than the attitude on government's performance in Radikal's publication policy in this period and thus articles are shaped accordingly. Radikal's equal distribution of articles in terms of their theoretical stance, not attitude toward government, seems to support this argument.

\section{Star}

111 articles examined in Star had mostly liberal and some constructivists themes. According to Star, the "Turkish sun" has emerged in the Middle East ${ }^{126}$ and Turkey, which has started to play "mediating and facilitating role in solving problems," has become increasingly visible in the region. ${ }^{127}$ Erdoğan's Davos outburst shows that Turkey, which has "unchained herself from her groundless fears such as Arab-phobia," 128 has become the country that oppressed "ones look for justice."129 Turkey also reads changing regional and global dynamics well, "craftily and steadily makes Israel irrelevant"130 and "broadens her field of maneuver to be able fill the power gap caused by the economic and political withdrawal of the US from the wider Middle East." "131 Particularly, "economy-oriented policies of Turkish FP in the new era has shattered our traditional perception of geography"132 and caused the emergence of a "Turkish Spring" in the region. ${ }^{133}$ Star, on the other hand, "emphasizes that the Turkey-EU relations has increasingly been weakening"134 and Turkish FP has been sailing dangerous in waters with the "New Ottomanism comedy."135

The pro-government stance of Star is evident in the articles and thus optimistic themes outweigh the theoretical background.

\section{Sabah}

Two hundred and two articles examined in Sabah are generally in the Optimistic category and possess liberal and econo-centric themes. Furthermore, Sabah's special effort to explain Obama-led US FP is evident. In total, 42 articles in Sabah specifically focus on Obama's FP, a focus that makes Sabah the leader in covering US FP among the newspapers examined. According to Sabah, Turkish FP in the new period, ${ }^{136}$ with the support of Turkey's "raising economic profile," 137 endeavors to "open up new markets"138 Sabah also emphasizes that, parallel to increased self-confidence of Turkey, "her ambition towards the EU membership has waned"139 since Turkey, with both Western and Islamic identity, has the advantage of being a "hybrid country" 140 and seeks to play a "more assertive role in the region." ${ }^{\prime 41}$ 
For Sabah, the Obama administration sees Turkey as a "model partner since Turkey's Muslim identity is crucial for US interests."142 The fact that the "US and Turkey have identical interests"143 "opens Turkey's opportunity venues in the region."144 "The US, in fact, aims to transform Israel by means of Turkey"145 and legitimizes "Turkey's regional leadership."146 "However, the most important obstacle between the US and Turkey is Iran." ${ }^{147}$ Moreover, the strained TurkeyIsrael relations that has come to the "point of breaking apart after the Mavi Marmara raid is another dilemma for the US to address."148

Although Sabah strongly emphasizes liberal themes, the pro-government stance of this newspaper triumphs over its liberal theoretical background. Therefore, positive attitude toward government's performance seems to lead the theoretical positioning of the articles. The fact that there is only one negative article (pessimist) among 202, which argues that the government has some limitations when tailoring the Turkish $\mathrm{FP}^{149}$ supports the prominence of Sabah's pro-government attitude.

\section{Taraf}

Twenty-eight of seventy-eight articles (35 percent) examined in Taraf address US FP or US domestic politics and thus are not directly related to the Turkish FP. According to Taraf, Obama's presidency has created a revolutionary impact in the world; and with Obama's victory, the politics of fear that ruled the world is over. ${ }^{150}$ For the Obama administration, the question of "Who is Turkey?" has become more important than the question of "Where is Turkey?"151 "Traditional elite in Turkey, representing the status quo, dislikes Obama since he represents hope and change."152 US-Turkey relations, however, especially on the issues of Israel, Iran and the PKK, have some "thorny" points. 153

Taraf also pays attentions to "the EU candidacy and asserts that EU process should not be seen as a matter of FP and should immediately be internationalized" ${ }^{154}$ so that the pace of the adoption of the EU reforms would be faster. ${ }^{155}$ It is evident that Taraf's liberal stance triumphs over its attitude toward government's performance. Among newspapers in the liberal and constructivist camp, Taraf is the harshest when criticizing the government. "The withdrawal of the government from Ermenian opening," ${ }^{156}$ AKP's not criticizing Iranian government during the Iranian presidential elections, ${ }^{157}$ "AKP's Islamist agenda that separate people as Muslims and nonMuslims when approaching any FP issue,"158 Turkey's close stance to Iran, Hamas and Omar el-Bashir ${ }^{159}$ and JDP's pro-Asad and pro-Kaddafi stance at the onset of crises in Syria and Libya ${ }^{160}$ are, for instance, severely criticized. It is, thus, highly likely to assert that the theoretical stance of Taraf leads to its attitude toward government's performance.

\section{Yeni Şafak}

With 53 articles among 106, Yeni Safak contributes to the Strongly Optimistic category, which shows its extreme pro-government stance. Interestingly, 27 articles 
out of 106 (24 percent) are about Israel and all severely criticize Israel, which makes this newspaper the one with the sharpest criticism toward Israel among 10 newspapers. According to Yeni Safak: in the new era, "Turkey has different FP priorities." 161 Turkey is "shaking off the burdens in its history luggage and reconstructing its identity"162 "has become a primary player in the region," 163 "with a motivation of responsibility towards its history." 164 Turkey recalls that she has "cultural and emotional area of influence beyond her borders" 165 and eventually has reverted back as a "leading country" of the Middle East, ${ }^{166}$ become a "play maker" in the region ${ }^{167}$ and even become a global power. ${ }^{168}$ Turkey, by searching for new markets in the Mesopotamia economic basin and "Caucasus economic basin"169 by undertaking a role in global conflicts, taking part in International organizations, by proactive reconciliation diplomacy and "zero problem" policy with neighbors ${ }^{170}$ offers "exciting, self-reliant and vigorous FP vision, and promises prosperity, stability and peace."171

On the other hand, according to Yeni Şafak; Turkey criticizes Israel because of the Gaza assault ${ }^{172}$ has gained status due to her attitude at Davos; ${ }^{173}$ "Israel has been trapped by the US-Turkey-Iran trio,"174 and "has isolated itself"175 by virtue of Obama's restraining policies, ${ }^{176}$ therefore the rules of the game in Turkey-Israel relationships have drastically changed. ${ }^{177}$ The Mavi Marmara Assault which is the "9/11 of Turkey," 178 has become a turning point in Turkey-Israel relations, ${ }^{179}$ Turkey holds a de jure position in this case ${ }^{180}$ and should immediately break off with Israel ${ }^{181}$ a "rogue state" that has lost her reason and morality. ${ }^{182}$

It is evident that the pro-government stance prevails over its theoretical stance in Yeni Şafak. The fact that there is only one negative article (Pessimist) among 106 that criticizes the Armenian opening ${ }^{183}$ supports this argument. Furthermore, the theoretical shifts of columnists are visible in Yeni Şafak. That is, some columnists, who have a strongly realist stance on the Turkey-Israel relationship, write strongly liberal pieces when it comes to Turkey's role in Wider Middle East. These theoretical contradictions are also good indicators of the prominence of the pro-government attitude over the theoretical stance in the Yeni Şafak case.

\section{Zaman}

Zaman is the main contributor both to the Strongly Optimistic category and the constructivist camp. While 96 articles among 106 are strongly optimistic, 32 articles among 106 are in the constructivist camp. In this context, Zaman is the most constructivist among the 10 newspapers analyzed. For instance, Zaman has 12 articles that scrutinize the phenomenon of power in world politics. According to Zaman, the changing balance in the international system "has made the traditional realist-centered power definition, that is materially defined military and economic power, alter." 184 Zaman, emphasizing "the rise of soft power" 185 and explaining this phenomenon as a consequence of Obama's new strategy in the evolving the world ${ }^{186}$ asserts that the time has come for "questioning the traditional power definitions in Turkey." 187 Soccer play would be used to melt the frozen conflicts between Turkey and Armenia as a means of "soft power" 188 and "Turkish TV serials that 
have been exported into the Middle East"189 are two good examples of Turkish soft power.

Besides, according to the Zaman, examining the phenomenon of fear in Turkish FP, the fundamental characteristics of the new world system are versatility and diversity. ${ }^{190}$ Claiming that a static axis has already vanished in world politics, for Zaman, the time has come to face "the ungrounded fears of geographical determinism"191 and "Turkey should immediately need to liberate herself from her pointless anxieties.",192 The dilemma that Turkey currently faces, for Zaman, is mainly based on fear of breaking apart the traditionally set but nonetheless "meaningless boundaries."193

According to Zaman, Turkey has evolved from "a wing country of Cold War years to a central country in the post-Cold War era"194 and turned from "object into subject." 195 Zaman claims that this changing role is not the choice for Turkey, it is in fact an "obligation to play." 196 By redesigning FP, Turkey; has "appeared on the scene" again after waiting its turn for a long time ${ }^{197}$ and has "started to play a mediator role between Islamic and Western world" 198 which might eventually lead to a "Pax Ottomana" 199 based on economic dependency in the region. ${ }^{200}$ On the other hand, "while Turkey's vision expands, Turkish politics and press has not yet been ready to this wider scope." 201

Moreover, both EU and Turkey are responsible for declaration of the EU candidacy process. ${ }^{202}$ Still, it may be useful to open the ports in Cyprus and withdraw soldiers partially as a gesture if EU candidacy is a main FP concern for Turkey ${ }^{203}$ which "has already got bored with EU candidacy."204

Although there are five negative articles (Pessimist) that criticize government's relationship with Omar el-Bashir, ${ }^{205}$ Kaddafi $^{206}$ and Turkey's diminishing appetite for the EU membership, ${ }^{207}$ most articles have pro-government stance in Zaman. Zaman's not taking a Hawkish stance when it comes to the Turkey-Israel relations, as Yeni Safak does, also deserves notice. In Zaman, the positive attitude on government's performance, therefore, seems to be the main driver of thematic structures rather than the theoretical stance driving attitude.

\section{Conclusion}

This analysis clearly shows that, among opinion leaders in Turkey, there continues a harsh debate about Turkish FP in the new era. This analysis also illustrates that Turkish FP has been in a paradigmatic transformation, defined by some as a grand failure and by others as a grand success. In terms of theoretical stance, however, the trend of this transformation would be described as a declining influence of traditionally set realist orientations in Turkish FP and the rise of liberal and constructivist ideas about the FP making process. Results also indicate that opinion leaders in the Turkish print media, who seem to be stuck in a "overstate/understate spiral" when assessing the AKP-run government's performance, have not been fully ready for theoretical reconstruction of Turkish FP. Relying on the analysis in this study, it appears that while some among 1535 articles take a negative or positive stance to this transformation because of the ideological/theoretical positioning of the 
columnists, the pragmatic pro/anti government attitude prevails and thus primarily shapes the thematic structures in a great majority of the articles.

Turkish FP in the new era, according to a hawkish realist and anti-government camp that includes Hürriyet, Cumhuriyet, Yeniçă̆ and Milliyet newspapers, is: imaginative and adventurous, situated amongst fact and fiction, sheared off and axis shifted, incautious, moving by senses not by reason, over individualized, careless of EU process, facing ideological shifts, populist, over integrated on internal politics, raising to the bait fast, has surrendered to the US track, romantic, imperial, pro-Iran, pro-Omer al-Bashir and pro-Hamas, not idealist on an universal perspective, new Ottomanist, having a lot of words to say but being futile, show oriented, causing crisis by spontaneous and sharp scolding performance. On the other hand, According to a dovish liberal/constructivist pro-government camp that comprises Star, Sabah, Taraf, Yeni Şafak and Zaman, the Turkish FP is multi-directional, multi-dimensional, principled, benign, standing with change and transformation, process oriented, mainly based on soft power, proactive and rhythmic, more independent, having regional and even global vision, economy oriented, coordinated with the US, aiming to be a bridge amongst Islam and the West, liberated from past fears, principled, the putting forward of moral politics, having historical responsibilities, getting harmonious with her Islamic identity, going to new markets such as Africa-China-South America-India, becoming protector of the helpless and a voice of the oppressed, honorable, standing strong and staid, not needy to the EU, an awaking giant, a rising sun.

One may, therefore, easily notice from the above-presented analyses of the newspapers that a great majority of the articles appeared in Zaman, Star, Sabah, Yeni Şafak and Taraf are the ones that seek to present an optimistic interpretation of Turkish FP. By contrast, a great majority of the articles that appeared in Hürriyet, Milliyet, Yeniçăg and Cumhuriyet are the ones that endeavor to spread pessimistic interpretation of the story. Radikal, however, which equally gave place for articles that includes realist, liberal, and constructivist themes, is found to be the most neutral newspaper among 10 newspapers examined.

One notable finding is that only a small number of articles address system-level changes such as the US-China rivalry, rising of the BRIC (Brazil, Russia, India and China) countries, effects of the global economic crisis on the international system, tension between Pakistan-India, Afghanistan, global warming, global security and terrorism. For instance, only 4 out of 1535 articles touch on China's rise and systematic effects of this rising, three articles deal with the Pakistan-India relationship, six articles talk about Afghanistan, and five articles mention events in Africa. In the light of these numbers, it seems that international issues are severely underrepresented in the articles analyzed, a disregard that contradicts the regional and even global vision of the Turkish FP in the new era. It is also interesting to note that only 69 articles (4.49 percent) among analyzed articles, the eighth mostly addressed issue in the corpus, are written on the EU and Turkey's candidacy process. The fact that the amount of articles related to the EU in the corpus is 
extremely low would be a good indicator of the fading interest of Turkey's opinion leaders on the $\mathrm{EU}$ in the new era.

In conclusion, conventional wisdom holds that "politics stops at the water's edge", that is, partisan politics concentrates on domestic affairs, whereas FP is (or maybe ought to be) governed by a domestic consensus on what is in the national interest. Relying on the analysis of the study, since domestic consensus has not been achieved in the print media, Turkish FP remains in the eye of the beholder. This study, nonetheless, suggests that Turkish FP in the new era is neither dreadful as hawks portray, nor marvelous as doves claim. To avoid the overstate/understate spiral, it would be convenient not to interpret every incident on Turkish FP through the lenses of proversus anti-government positioning. One should note that portraying of every incident either as an absolute victory or an absolute defeat does not help shape a healthy public opinion about FP.

All opinions expressed above are those of the author alone and do not necessarily represent the views of any institution or organization the author has been associated with.

\section{Acknowledgements}

The author thanks Prof. Saime Özçürümez Bölükbaşı from the Bilkent University, Turkey and Prof. Clark McCauley from Bryn Mawr College, USA for their valuable contributions and encouragements.

\section{Notes}

1. Davutoglu, "Turkey's Zero-Problems Foreign Policy."

2. Ibid.

3. Ibid.

4. Ekrem Dumanlı "Ülkenin vizyonu büyürken" (Zaman, October 12, 2009).

5. von Krippendorff, Content Analysis, 14.

6. Weber, Basic Content Analysis, 12.

7. Hsieh and Shannon, "Three Approaches to Qualitative Content Analysis," 1277-88.

8. Hüseyin Baş, "Kafkasya Savaşından Ders Çıkarmak" (Cumhuriyet, September 8, 2008).

9. Cüneyt Ulsever, "Lizbon Zincirini Nasıl Okuyalım?" (Hürriyet, November 25, 2010).

10. Temel İskit, "Büyüyen Türkiye-Devam" (Taraf, November 2, 2010).

11. Özcan Yeniceri, "Çelişki, Güç ve İlişkiler" (Yeniçag, September 10, 2008).

12. Nejat Eslen, "Türkiye Küresel Bir Güç mü?" ( Radikal, August 15, 2009).

13. Sedat Ergin, "Türkiye çekimser kalmalıydı" (Hürriyet, June 11, 2010).

14. Cüneyt Ülsever, “Ahmet Davutoğlu: Bir efsanenin çöküşü (mü?)” (Hürriyet, November 24, 2010).

15. Cüneyt Ülsever, "Bunlar tutarlı dış politika gösergeleri mi?" (Hürriyet, January 21, 2010).

16. Kürşad Zorlu, "Osmanlı Millet Topluluğu en çok kime zarar verir?” (Yeniçă̆, December 11, 2010).

17. Okan Müderrisoğlu, "Yumuşak gücün sırrı" (Sabah, July 23, 2009).

18. Fehmi Koru, "Yeni Türkiye tablosu" (Yeni Safak, October 2, 2009).

19. Ali Bayramoğlu, "Hala Erivan'dayız" (Yeni Safak, September 9, 2008).

20. Fehmi Koru, "Yarı Başkanlık Sistemi bize uyuyor mu?" (Yeni Safak, October 4, 2009).

21. J.Ahonosiadis, "Türk Dış Politikası fark yaratıyor" (Radikal, January 15, 2009).

22. Kürşat Bumin, "İnasni yardımlar ve dış politika" (Yeni Safak, June 2, 2010). 
23. Akif Emre, "Ortadoğu'da aşağılanmış barış" (Yeni Safak, May 20, 2008).

24. Yasin Aktay, "Diyarbakır'a Erbil üzerinden bir yol" (Yeni Safak, November 7, 2009).

25. Bülent Korucu, "Cihanda sulh yurtta sulh" (Zaman, September 9, 2008).

26. Mümtazer Türköne, "Dik durmak ama diklenmemek" (Zaman, February 1, 2009)

27. H.Bülent Kahraman, "İsrail'i Türkiye ile dönüştürmek" (Sabah, October 21, 2009).

28. Taha Akyol, "Basın boykotu" (Milliyet, September 20, 2008).

29. H.Bülent Kahraman, "Nasıl görünüyor uzaktan Türkiye?” (Sabah, September 29, 2010).

30. Cengiz Çandar, "türkiye'nin yönü neresi?" (Radikal, October 31, 2009).

31. Morgenthau, Politics among Nations, 5-14.

32. Snyder, "One World, Rival Theories," 52-62.

33. Walt, "International Relations," 29-46.

34. Brooks, "Dueling Realisms," 445-77.

35. Jervis, "Neoliberalism and Cooperation," 42-63.

36. Keohane and Nye, Power and Interdependence, 20-7.

37. Kupchan, "Minor League, Major Problems," 96-109.

38. Talbot, The Great Experiment, 8-9.

39. Checkel, "The Constructivist Turn in International Relations Theory," 324-49.

40. Wendt, "Anarchy is What States Make of It," 391-425.

41. Ruggie, "What Makes the World Hang Together?", 855-85.

42. Nye, Soft Power, 18-22.

43. Hopf, "The Promise of Constructivism in International Relations Theory," 171-200.

44. Nuray Mert, "Obama'nın elini sıkmanın bedeli" (Radikal, April 7, 2009).

45. Tufan Türenc, "Takdiri ilahi değil düpedüz cinayet" (Hürriyet, April 8, 2008).

46. Ferai Tınç, "Türban reformları sulandıracak" (Hürriyet, February 1, 2008; January 25, 2009).

47. Yalçın Dogan, "En büyük kabadayı bizim kabadayı" (Hürriyet, January 31, 2009).

48. Yalçın Dogan, "Gazze-Sudan arasında Cuma Hutbesi" (Hürriyet, May, 2 2009).

49. Ferai Tınç, "Halka başka dışarıya başka" (Hürriyet, February 22, 2009).

50. Cüneyt Ülsever, "Obamania (İnşallah) sona ererken" (Hürriyet, April 16, 2009).

51. Cüneyt Ülsever, "Cemaat ve TSK" (Hürriyet, April 23, 2009).

52. Cüneyt Ülsever, "Ülke yanılttlıyor mu?" (Hürriyet, April 29, 2009).

53. Sedat Ergin, "Yedi maddelik bir dış politika testi" (Hürriyet, August 31, 2009).

54. Cüneyt Ulsever, "Gizli görüşme gizli olur" (Hürriyet, July 4, 2010).

55. Eyüp Can, "Türkiye kazan kazandan kaybet kaybete sürükleniyor" (Hürriyet, June 16, 2010).

56. Sedat Ergin, "Türkiye Batıya dönük yön duygusunu kaybediyor" (Hürriyet, October 18, 2010).

57. Cüneyt Ulsever, "Hayal ile gerçek arasında dış politika" (Hürriyet, May 1, 2011).

58. Cüneyt Ülsever, "Hayal ile gerçek arasında: Biz bize yeteriz" (Hürriyet, January 16, 2011).

59. Oktay Eksi, "Bu nasıl başarı?" (Hürriyet, June 26, 2010).

60. Cüneyt Ülsever, "Türkiye'nin yeni dış politikası” (Hürriyet, October 15, 2009).

61. Cüneyt Ülsever, "Obama’ya nobel bayılana gazoz” (Hürriyet, October 11, 2009).

62. Cüneyt Ülsever, "El Beşir hoş geldin” (Hürriyet, August 11, 2009). Ferai Tınç, "Bir düşünce haritası pusulası" (Hürriyet, September 11, 2009).

63. Ferai Tınç, "Eksen kaydı mı kaymadı mı?" (Hürriyet, June 11, 2009).

64. Cüneyt Ulsever, "Bunlar tutarlı dış politika göstergeleri mi?" (Hürriyet, January 21, 2010).

65. Sedat Ergin, "Batıdaki Türkiye algısı değişiyor" (Hürriyet, December 6, 2010).

66. Oktay Ekşi, "Hala batılı mıyız?" (Hürriyet, June 13, 2010).

67. İlker Türkmen, "2009'da Ortadoğu ve Kafkasya” (Hürriyet, November 1, 2008); Hadi Uluengin, "Efe Rusya" (Hürriyet, September 2, 2008).

68. Şükrü Küçükşahin, "Güll’ün Honduras meraksızlığı" (Hürriyet, July 6, 2009).

69. Eyüp Can, "Cihanda barış, yurtta savaş" (Hürriyet, May 7, 2010); Hadi Uluengin "Eksen kayması mı?" (Hürriyet, June 12, 2010).

70. Ertuğrul Özkök, "Kimmiş o konuşan yetkili?" (Hürriyet, July 11, 2009). 
71. Hadi Uluengin, "Eksen Kayması mı?" (Hürriyet, June 12, 2010); Fatih Cekirge (Hürriyet, February 1, 2011; I.Kalin [interview] May 8, 2011).

72. Yalçın Dogan, "En büyük kabadayı bizim kabadayı" (Hürriyet, January 31, 2009).

73. Ferai Tınç, "Türkiye Obama’nın Ortadoğu muhatabı değil”" (Hürriyet, Janury 25, 2009).

74. Ferai Tınç, "Türkiye Obama'nın Ortadoğu muhatabı değil" (Hürriyet, January 25, 2009).

75. Cüneyt Ülsever, "Son Osmanlı padişahı: 1. Tayyip Erdoğan” (Hürriyet, March 4, 2009).

76. Yalçın Dogan, “Avrupa'nın Hugo Chavez'I var: Tayyip Erdoğan” (Hürriyet, April 7, 2009).

77. Ahmet Hakan, “Ahmet Davutoğlu efsanesi yıkılacak" (Hürriyet, May 3, 2009).

78. Ezgi Başaran, “Ahmedinejad'la yan yana poz vermemeliydik” (Hürriyet, June 17, 2010).

79. Cüneyt Ülsever, “ Bir İllüzyonun önlenemez çöküşü” (Hürriyet, June 24, 2010).

80. Cüneyt Ülsever, "İmzasının arkasında duramayan devlet olur mu?" (Hürriyet, October 6, 2009).

81. Cüneyt Ülsever, "Küresel cihat" (Hürriyet, June 6, 2010).

82. Tufan Türenç, "Cihat kafasıyla uluslararası sorunlar çözülemez" (Hürriyet, June 14, 2010).

83. Utku Çakırözer, "İşte dış politikada çifte standart" (Cumhuriyet, February 23, 2011).

84. Şükran Soner, "Abd kıskacında AKP” (Cumhuriyet, January 12, 2010).

85. Soner Cağaptay, "Türkiye Batı'dan uzaklaşıyor” (Cumhuriyet, November 1, 2010).

86. Mustafa Balbay, "Ortadoğu bataklığı ve Türkiye'nin yeri” (Cumhuriyet, June 6, 2008).

87. Orhan Birgit, "Dış politikamızda makas değiştiriyoruz" (Cumhuriyet, June 9, 2010).

88. Mustafa Balbay, "Terörle 1lımlı mücadele" (Cumhuriyet, January 11, 2008).

89. Cüneyt Arcayürek, "Dış politikada DAvutoğlu açılımları" (Cumhuriyet, December 8, 2010).

90. Ergin Yıldızoglu, "Stratejik derinlik daha da derinleşirken" (Cumhuriyet, June 27, 2010).

91. Orhan Bursalı, "Davutoğlu'nu dinlerken" (Cumhuriyet, December 26, 2010).

92. Cüneyt Arcayürek, "Dış politikada Davutoğlu açılımı" (Cumhuriyet, December 8, 2010).

93. Mustafa Balbay, "Çok kişilikli dış politika" (Cumhuriyet, August 26, 2008).

94. Ümit Özdağ, "Osmanlı Milletler Topluluğu” (Yeniçağ, December 27, 2010).

95. Altemur Kılıç, "Yavru Egenekon" (Yeniçă̆, October 4, 2009).

96. Selcan Taşç1, "Gördüğünüzün farkıda mısınız?" (Yeniçağ, April 18, 2009).

97. Altemur Kılıç, "Farklılıkların cumhurbaşkanı" (Yeniçağ, October 3, 2009).

98. Özcan Yeniçeri, "Evlere şenlik dış politika" (Yeniçağ, April 5, 2011).

99. Savaş Sözal, "Türkiye dalgalı denizde sisler arasına giriyor." (Yeniçağ, September 18, 2009).

100. Özcan Yeniçeri, "Evlere şenlik diş politika" (Yeniçağ, April 5, 2011).

101. Aslan Bulut, "Gül ve Erdoğan'dan ABD Rusya arasında tahtarevalli politikası” (Yeniçă̆, February 17, 2009).

102. Semih Idiz, "Erdoğan'ın İsrail çıkışı Ankara için sorun yaratabilir" (Milliyet, December 29, 2008).

103. Semih Idiz, "Erdoğan'ın Darfur Çelişkisi” (Milliyet, February 5, 2009).

104. Sami Kohen, "Frekans ayarı" (Milliyet, November 10, 2009).

105. Kadri Gürsel "İran sınavı Davutoğlu'nu terletecek" (Milliyet, September 10, 2009). Rıza Türmen "Dış politikada kuşkular doğuyor" (Milliyet, January 23, 2009). Semih Idiz "Erdoğan'ın Darfur çelişkisi" (Milliyet, May 2, 2009). Sami Kohen, "Türkiye taraf değil, ama ..." (Milliyet, June 3, 2009). Kadri Gürsel, “AKP'nin derin İran politikası” (Milliyet, April 15, 2010).

106. Semih İdiz, "Diplomasi AKP’ye birkaç gömlek büyük gelmeye başladı" (Milliyet, March 7, 2009).

107. Semih İdiz, "Davutoğlu sözlerini daha dikkatli seçmeli" (Milliyet, September 7, 2009).

108. Kadri Gürsel, "Bir Davutoğlu polemiği" (Milliyet, May 7, 2009).

109. Doğan Heper, "Eksen kaymalı mı, yoksa?" (Milliyet, June 17, 2010).

110. Rıza Türmen, "Yeni Türk dış politikası" (Milliyet, January 24, 2011).

111. Kadri Gürsel, “İsrail AKP'nin nasıl şamar oğlanı oldu?” (Milliyet, October 19, 2009).

112. Sami Kohen, "Cumhuriyetin diş politika kriterleri" (Milliyet, September 29, 2008).

113. Doğan Heper, "Hem Araplar, hem İsrail" (Milliyet, August 22, 2009).

114. Cengiz Çandar, “Obama'nın barışcıl öncü kuvveti olarak Tahran'da” (Radikal, March 11, 2009).

115. Xavier Batolla, "Ankara'nın dış politika sayesinde bölgesel ağırlı̆̆ı artıyor” (Radikal, December 22, 2008).

116. Saad Muhyu, “AKP Osmanlı'yı diriltiyor” (Radikal, September 16, 2008). 
117. R. al-Sayyid, "Türkiye İsrail ve İran'dan daha çekici” (Radikal, November 12, 2009).

118. Özdem Sanberk, "Dış politikada yeni bir başlangıç mı?" (Radikal, May 22, 2009).

119. Murat Yetkin, "Hangi AB hangi AKP" (Radikal, December 13, 2011).

120. Cengiz Candar, "Çözüm değil süreçler önemli" (Radikal, May 5, 2009).

121. M. Herzog, "İsrail yeni Türkiye'nin doğal kurbanı oldu" (Radikal, December 16, 2010).

122. J. Abonosiadis, "Türk dış politikası fark yaratıyor" (Radikal, January 15, 2009).

123. Cengiz Candar, "Türkiye'nin yönü neresi?" (Radikal, August 31, 2009).

124. Cengiz Candar, "Ahlaksız ya da çifte ahlak ölçülü dış politika olmaz" (Radikal, February 1, 2011).

125. Hasan Celal Güzel, "Ve dev uyanıyor" (Radikal, October 21, 2008).

126. Aziz Üstel, "Ve Ortadoğu'da Türkiye güneşi doğuyor" (Star, July 20, 2008).

127. Mustafa Karaalioğlu, "Osetya'dan Brüksel'e bir yol” (Star, August 21, 2008).

128. Mustafa Akyol, "İkinci Davutoğlu dönemi" (Star, May 4, 2009).

129. Şamil Tayyar, "Emir komuta zinciri kırıldı" (Star, August 4, 2009).

130. İbrahim Kiras, "Türkiye güçlendikçe İsrail önemsizleşiyor" (Star, October 15, 2009).

131. Aydan Zenturk, "2025: Amerikasız dünya" (Star, October 29, 2009).

132. Nasih Güngör, "Suriye'ye dudak bikmek" (Star, December 25, 2009).

133. Sedat Laçiner, "Arab Baharında BAtı'nın rolü” (Star, April 26, 2011).

134. Beril Dedeoğlu, “2008'de doğu 2009'da batı olur mu?" (Star, January 2, 2009).

135. Aydan Zentürk, "Yeni-Osmanlı komedisi" (Star, February 12, 2009).

136. Erdal Şafak, "Bir millet uyanıyor" (Sabah, November 12, 2009).

137. Erdal Şafak, "New York yolunda" (Sabah, September 21, 2008).

138. Soli Özel, "Yükselen profil" (Sabah, September 7, 2008).

139. Nur Batur, "On y1l sonar üye olursunuz" (Sabah, February 11, 2008).

140. H. Bülent Kahraman, "Nasıl görünüyor uzaktan Türkiye?" (Sabah, September 29, 2010).

141. Talip Küçükcan, "Türkiye blgede düzen kurucu rol üstleniyor" (Sabah, January 22, 2011).

142. Ömer Taspinar, "Ulusalcılara kötü haber; ABD ile model ortaklık başlıyor" (Sabah, April 20, 2009).

143. Nazlı Ilıcak, "Davutoğlu ve eksen kayması" (April 26, 2009).

144. Okan Müderrisoğlu, "Uçakta Afganistan mesajı: Savaşmayız" (Sabah, December 7, 2009).

145. H.Bülent Kahraman, "İsrail ile Türkiye’yi dönüştürmek" (Sabah, October 21, 2009)

146. İbrahim Kalın, "İç tehdit algısı ve dış politika" (Sabah, February 16, 2010).

147. Ömer Taspinar, "ABD ile asıl sorun İran,İsrail değil" (Sabah, July 5, 2010).

148. Ömer Taspinar, "Türkiye üzerine iki farklı analiz" (Sabah, August 16, 2010).

149. Burhanettin Duran, "arap Baharı ve dış politikanın sınırları" (Sabah, October 1, 2011)

150. Yasemin Çongar, "Biz aşağıda imzası olan ABD vatandaşları" (Taraf, January 21, 2009).

151. Yasemin Çongar, "Obama Türkiye'ye küresel rol önerdi" (Taraf, April 8, 2009).

152. Önder Aytac-Emre Uslu, "Devlet eliti Obama'yı neden sevmiyor?" (Taraf, November 3, 2008).

153. Evrim Bunn, "Washington'un Ankara'dan beklentisi" (Taraf, June 29, 2010).

154. Yasemin Çongar, “AB'yi dış politika konusu olmaktan çıkarmanın tam zamanı” (Taraf, August 6, 2008).

155. Temel İskit, "Rapora gerek mi var?" (Taraf, October 21, 2008).

156. Markar Esayan, "Ermeni açılımında aranan tıkaç bulundu." (Taraf, Januray 21, 2010).

157. Yasemin Çongar, "Yaptırımlar ve yeşiller" (Taraf, June 10, 2010).

158. Ahmet Altan, "Ülke ve Parti" (Taraf, June 17, 2010).

159. Evrim Bunn, "Türkiye'yi kim istemedi?" (Taraf, November 16, 2010).

160. Kurtuluş Tayiz, "Yeni dünyanın aynası" (Taraf, March 22, 2011).

161. Davut Dursun, "Yeni Türkiye Cumhuriyeti" (Yenişafak, July 17, 2008).

162. Ali Bayramoglu, "Hala erivan'dayız" (Yenişafak, September 9, 2008).

163. İbrahim Karagül, "Beş yıl sonar da onun büyük projesi çöker" (Yenişafak, December 23, 2008).

164. B. Musa Nafi, "Ve yeni Osmanlılar sahnede" (Yenişafak, February 15, 2009).

165. Yasin Aktay, "Diyarbakır'a Erbil üzerinden bir yol” (Yenişafak, Novmeber 7, 2009).

166. Akif Emre, "Ortadoğu'ya dönmenin anlamı" (Yenişafak, February 17, 2009).

167. İbrahim Karagül, "Mukteda Sadr, Türk Baasçıllı̆̆ ve bir iddia” (Yenişafak, May 5, 2009). 
168. Fehmi Koru, "Mayınlara basmayınız" (Yenişafak, May 28, 2009).

169. F.Koru, "Yeni Türkiye tablosu" (Yenişafak, October 2, 2009).

170. Fehmi Koru, "Yeni Türkiye tablosu" (Yenişafak, October 2, 2009).

171. Fehmi Koru, "Zürih'te atılan imzaların anlamı" (Yenişafak, October 11, 2009). Ali Bayramoglu "Türkiye'ye neler oluyor?" (Yenişafak, October 17, 2009).

172. Akif Emre, "İsrail, Filistin Türkiye ilişkileri" (Yenişafak, January 8, 2008).

173. Ali Bayramoglu, "Bir başbakan, bir lider, bir duruş" (Yenişafak, January 31, 2009).

174. Turan Ayhan, "Türkiye-ABD ve İran üçgeninde İsrail" (Yenişafak, February 6, 2009).

175. Taha Kivanc, "aferin israil'e kendini yanlızlaştırdı” (Yenişafak, October 20, 2009).

176. Yasin Aktay, "Çivi çiviyi söker, budur bunun ilacı" (Yenişafak, October 19, 2009).

177. İbrahim Karagül, "İsrail Türkiye'yi durdurabilir mi?" (Yenişafak, November 6, 2009).

178. Taha Kıvanç, "Bir eski kaptanın Gazze seyir defteri" (Yenişafak, June 11, 2010).

179. Murat Aksoy, "Merak değil tehdit sorusu:eksen mi kayıyor?" (Yenişafak, June 14, 2010).

180. Ali Bayramoglu, "Mavi Marmaranın Türkiye’yi götürdüğü liman” (Yenişafak, June 9, 2010).

181. Resül Tosun, "Derhal Fesih" (Yenişafak, June 16, 2010).

182. Yasin Doğan, "Kadim dostumuz ABD" (Yenişafak, June 17, 2010).

183. Kürşat Bumin, "Yarg1, bizi çıldırtmadan" (Yenişafak, October 5, 2009).

184. Levent Koker, "Türkiye'de siyaset tartı̧̧maları ve bölünmüş Batı" (Zaman, February 12, 2009).

185. Gökhan Bacık, "Değişen algılar ve yeni firsatlar dönemi" (Zaman, February 11, 2009).

186. İhsan Dağı, "Türkiye için Obama ne demek?" (Zaman, January 20, 2009). Ali Aslan, "senkronizasyon Baharı" (Zaman, June 8, 2009).

187. Mehmet Yılmaz, "Türkiye'nin gücü” (Zaman, May 4, 2009).

188. İhsan Dağı, "Cesur Yürekler: Gül ve Terim” (Zaman, September 5, 2008). A. Ibadou, "Sarkisyan'ın elindeki tarihi firsat" (Zaman, August 8, 2008).

189. B.Tuveysi, "Türkiye'nin esnek gücü ve TRT7" (Zaman, October 7, 2009).

190. Ekrem Dumanlı, "Dış politikanın yeni parametreleri ve Türkiye gerçeği” (Zaman, May 4, 2010).

191. Bülent Korucu, "Cihanda sulh, yurtta sulh" (Zaman, September 9, 2008).

192. İhsan Dağı, "Kim korkar açılımdan?" (Zaman, October 13, 2009).

193. Ali Aslan, "Erdemli gücün performansı" (Zaman, April 28, 2012).

194. Muhammed Berhume, "Taraf ülkeden merkez ülkeye" (Zaman, May 3, 2009).

195. Beril Dedeoglu, "AB,Türkiye ve Rusya:Firsatlar dönemi mi?” (Zaman, August 10, 2009).

196. Abdulhamit Bilici, "Hoca'nın iddiası ve şansı" (Zaman, December 28, 2010).

197. Ali Aslan, "Süpermen Davutoğlu, Vaşington nasıl geçti?" (Zaman, March 28, 2009).

198. Ali Bulaç, "Kendimizi yanlış anlıyoruz" (Zaman, May 4, 2009).

199. M. Türköne, "Yeni Osmanlı" (Zaman, December 16, 2010).

200. Nuri Yurdusev, "Osmanlı Milletler Topluluğu: Hayal mi gerçek mi?” (Zaman, December 15, 2010).

201. Ekrem Dumanlı, "Dişa açılan türkiye'de basın nerede?" (Zaman, October 12, 2009; I. Dagi, June 18, 2010).

202. J. Lagendjik, "Yavaşlamanın kabahati hem AB'de hem Türkiye'de" (Zaman, December 19, 2010).

203. Şahin Alpay, "Eğer Ab'ye üyelik temel dış politika hedefi ise" (Zaman, November 11, 2010).

204. İhsan Dağı, "AB'den bıktıysak ne yapalım?" (Zaman, November 12, 2010).

205. Şahin Alpay, "Dış poitikada realizm ve idealizm" (Zaman, October 4, 2008).

206. İhsan Dağı, "Kaddafi bizden biri mi?" (Zaman, March 22, 2011).

207. J. Lagendjik, "Yavaşlamanın kabahati hem AB'de hem Türkiye'de" (Zaman, December 19, 2010).

\section{Notes on contributor}

Metin Gurcan holds an MA degree in Security Studies from the US Naval Postgraduate School in Monterey, CA. Currently, he is a PhD candidate at the Department of Political Science in Bilkent University studying civil-military relations in Turkey, the changing nature of warfare in the twenty-first century and the relationship between national security and foreign policy-making. He has many scholarly published articles that both appeared in international and Turkish academic journals. 


\section{Bibliography}

Brooks, Stephen G. "Dueling Realisms.” International Organization 51, no. 3 (1997): 445-477.

Checkel, Jeffrey T. "The Constructivist Turn in International Relations Theory." World Politics 50, no. 2 (1998): 324-349.

Davutoglu, Ahmet. "Turkey’s Zero-Problems Foreign Policy." Foreign Policy, May 10, 2010. Accessed December 12, 2011. http://jft-newspaper.aub.edu.lb/reserve/data/s11244/s11244.pdf

Hsieh, H.-F., and S. E. Shannon. "Three Approaches to Qualitative Content Analysis." Qualitative Health Research 15, no. 9 (2005): 1277-1288.

Hopf, Ted. "The Promise of Constructivism in International Relations Theory." International Security 23, no. 1 (1998): 171-200.

Robert Jervis. "Neoliberalism and Cooperation: Understanding the Debate." International Security 24, no. 1 (1999): 42-63.

Keohane, Robert O., and Joseph Nye. Power and Interdependence: World Politics in Transition. Glenview: Foresman, 1989.

von Krippendorff, Klaus. Content Analysis: An Introduction to its Methodology. Newbury Park: Sage Publications, 2004.

Kupchan, Charles A. "Minor League, Major Problems: The Case against a League of Democracies." Foreign Affairs 87, no. 6 (2008): 96-109.

Morgenthau, Hans J. Politics among Nations. New York: McGraw-Hill, 1993.

Nye, Joseph S. Soft Power. New York: Public Affairs, 2004.

Ruggie, John Gerard. "What Makes the World Hang Together? Neo-Utilitarianism and the Social Constructivist Challenge.” International Organization 52, no. 4 (1998): 855-885.

Snyder, Jack. "One World, Rival Theories.” Foreign Policy, no. 145 (2004): 52-62.

Talbot, Strobe. The Great Experiment. New York: Simon \& Schuster, 2008.

Walt, Stephen M. "International Relations: One World, Many Theories.” Foreign Policy, no. 110, Special Edition: Frontiers of Knowledge (Spring, 1998): 29-46.

Weber, Robert Philip. Basic Content Analysis. Newbury Park, CA: Sage Publication, 1990.

Wendt, Alexander. "Anarchy is What States Make of It: The Social Construction of Power Politics." International Organizations 46, no. 2 (1995): 391-425. 